\title{
有機溶媒中のマグネシウムのフレーム原子吸光分析における 還元性粉体の添加効果
}

\author{
(1987 年 2 月 12 日 受理) \\ 吉 村 長 蔵・藤 野 隆 由*
}

\begin{abstract}
1 緒 言
フレーム原子吸光分析に执いて，種々の元素を対象としてその 水溶液中でのカーボンブラック（以下 $\mathrm{CB}$ と略記する）の添加効 果についてはすでに報告した1) 4)。また，有機溶媒の添加効果に ついてはすでに多くの報告がある(5)代が，精度および再現性の点 で満足のいくものでない。本報では, 還元性粉体（金属水素化物, 硫黄および CB）の添加によって増感するアルカリ土類金属中で もっとも増感率が高く, 高感度が得られるマグネシウムを対象と した場合に，さらに感度の向上を目的として，これら還元性粉体 を $N, N$-シメチルホルムアミド (以下, DMF と略記する), ジ メチルスルホキシド（以下, DMSO と略記する) 拉よび水溶液 に超音波分散した陚料溶液についてその添加効果を比較した。
\end{abstract}

\section{2 実験}

\section{1 装 置}

原子吸光光度計 : 島津裂作所集 A A 630-12

記録計 : 島津製作所䧶 U-135

分散器 : ブランソン留ブランソニック 12

\section{2 試 薬}

標準溶液は，関東化学隻原子吸光分析用標準液 (1000 ppm) を 母液とし、これを適宜, 希釈使用した。DMF および DMSO は Karl Fischer 法滴定の結果，約 $0.03 \%$ の水を含有していた。 $0.5 \mathrm{w} / \mathrm{v} \% \mathrm{CB}$ (三药化成 \#44, 平均粒子径 $21 \mathrm{~nm}, \mathrm{pH} 7.5$ ) の 保存溶液は，上記溶媒に分散させ調製した。同様に， $1 \mathrm{w} / \mathrm{v} \%$ の 水素化カルシウム, 水素化リチウムは市肘特級品を用い, その $2.50 \mathrm{~g}$ をそれぞれ DMF および DMSO 溶媒で $250 \mathrm{~m} l$ 定容と したのちに約 10 分間の超音波照射を行なって均一分散した。そ のほか, 試薬類はすべて特級品を用いた。

\section{3 結果および考察}

\section{1 アルカリ土類金属に対する CB の添加効果の比較}

フレーム原子吸光分析に扣いて, アルカリ土類金属の感度は全 般的に高く,なかでもマグネシウムは高感度定量元素の一つとさ

近畿大学理工学部応用化学教室, 577 東大阪市小若江

1）吉村長藏, 森本豊文, 日化, 1976, 1522.

2）吉村長藏, 森本豊文, 日化, 1977, 1334.

3）吉村長藏, 野田義則, 日化, 1978, 1098.

4）吉村長藏, 野田義則, 日化， 1978，561.

5) V. K. Panday, A. K. Gunguly, Anal. Chim. Acta., 52, 417(1970).

6) J.E. Allan, Spectrochim. Acta, 17, 710(1961).
れている。それは, 分析線強度が高く, 空気ーアセチンン炎の温度 で容易に原子化されるなどの理由による。そこで予備実験として 空気ーアセチレン炎を用いマグネシウムとほかのアルカリ土類金 属に対する CB の添加効果の比較を行なった。表 1 に $1 \%$ 吸光 感度および精度を示した。アルカリ土類金属中, マグネシウムの 増感率が $143 \%$ と一番高く，ついでカルシウム，ストロンチウ ム, パリウムの順に増感率が低下した。すなわち，周期表の下段 へいくにしたがい增感率が低下する佰向が認められた。測定感度 は，炎中でそれぞれの塩が熱分解したのちに生成する酸化物（非 化学量論的）の安定性とその酸化物へ生成速度に左右される。し たがって，表 1 のよらに同族元素に拈いて CB の添加による増感 率が異なるのは, $\mathrm{CB}$ のもつ安定な酸化物の生成を㧕制する効果 がそれぞれの元素について異なるのと，カーパイドなどを生成し やすい金属が安定化し，原子化效率が低下したためと考克られ る。また，测定精度では，空気ーアセチレン炎を用いた場合， CB

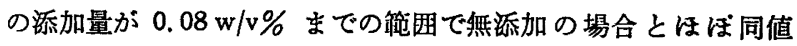
（変動係数 $3.9 \%$ ）の精度が得られた。

\section{2 有機溶媒の影響}

マグネシウムの定量時に,メタノール、エタノール，アセトン のよらな有機溶媒の添加によって井光感度が増大することは報告 されている。本研究では, DMFゃDMSOなどの有機搈媒の影 響について検討した。図 1 に, マグネシゥムの吸光度に対する水 と DMF および DMSO との混合比の影響を示した。その結果, 15\% 以下の DMF を含む水溶液では吸光度は減少したが, それ 以下の DMF の添加で吸光度は增大した。さらに, 水を含まない $\mathrm{DMF}$ 溶液と水溶液とを比較すると, 吸光度は約 2 倍に增大する

Table 1 Effect of $0.08 \mathrm{w} / \mathrm{v} \%$ carbon black on sensitivity and coefficient of variation of alkaline earth metals

\begin{tabular}{lccc} 
Element & $\begin{array}{c}\text { Sensitivity } \\
(\mu \mathrm{g} / \mathrm{m} l)\end{array}$ & $\begin{array}{c}\text { Coefficient of } \\
\text { variation } \\
(\%)\end{array}$ & $\begin{array}{c}\text { Enhancing } \\
\text { effect } \\
(\%)\end{array}$ \\
\hline Beryllium $^{a)}$ & 0.010 & 5.7 & +41 \\
Magnesium $_{\text {Calcium }}$ & 0.0025 & 3.6 & +143 \\
Strontium & 0.027 & 3.2 & +92 \\
Barium $^{a)}$ & 0.034 & 4.9 & +58 \\
& 0.83 & 5.1 & +26
\end{tabular}

a) Beryllium and barium were measured with dinitrogen oxide-acetylene flame, air-acetylene flame was used for the other metal ions.

$b$ ) Determined by five times measurements.

+ : Increase amount. 


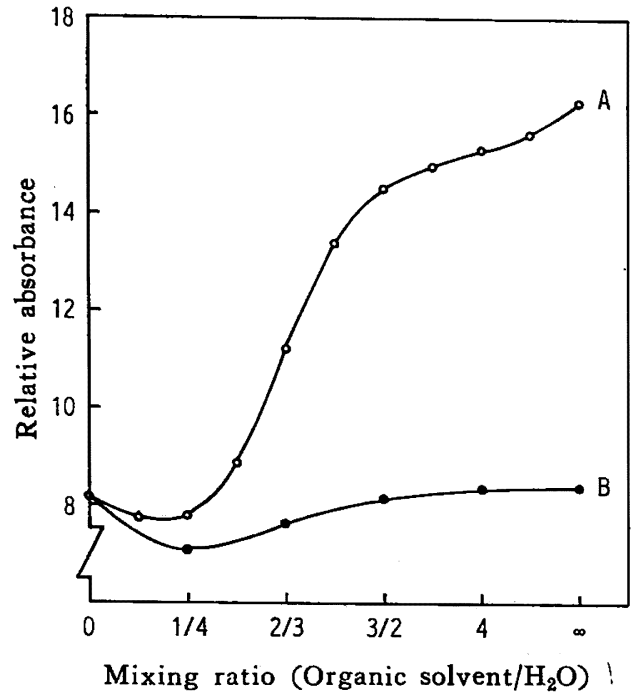

Fig. 1 Influence of the mixing ratio of water and organic solvents on magnesium absorbance

Sample: $\mathrm{MgCl}_{2}(\mathrm{Mg}, 0.05 \mathrm{ppm})$

Curves : A ; DMF, B ; DMSO

Air flow rate $: 13 l / \mathrm{min}$

Acetylene flow rate $: 1.8 \mathrm{l} / \mathrm{min}$

Wavelength : $285.2 \mathrm{~nm}$

Height of beam above burner head : $5 \mathrm{~mm}$

\section{ことが認められた。}

一方, DMSO 溶液の場合は，水之の混合比にかかわらす吸光 度変化はなかった。このような有機溶媒の影響は，化学的干渉や 物理的干涉が関与すると考えられる。そこで，表 2 に示すよう に，10 cm スロットバーナーを用いたときの水溶液，DMF およ び DMSO 溶液の噴霧量を測定した。噴霧量は吸込量とドレイン への排水量を測定することによってその差から求めた。試料溶液 の吸込量は，水と DMF とではあまり変化はないが，排水量で約 1.5 倍の差を生した。このように DMF を溶媒とすることで感 度が上がるのは，噴霧の絶対量が変化するためであり，その噴霧 量の変化は, 溶媒の粘度・表面張力・蒸気圧の相違が原因で起こ ると考えられる。

\section{3 還元性粉体と有機溶媒との相乗効果}

水素化物と有機溶媒との相乗効果については，結果を図 2 に示 した。DMSO 溶液中に执いて水素化カルシウムの添加は非常に 効果的であり, 無添加時と比較して吸光度は約 2.5 倍に増大し た。また，DMF を溶媒とした場合にも約 $20 \%$ の增感が認めら れ, 有機溶媒との相乗効果が確認された。しかし, 水素化りチウ

Table 2 Spray quantity of water, DMF and DMSO by using a $10 \mathrm{~cm}$ slot burner

\begin{tabular}{|c|c|c|c|}
\hline Solvent & $\begin{array}{c}\text { Inhalation rate } \\
(l / \mathrm{min}) \\
\alpha\end{array}$ & $\begin{array}{c}\text { Drain rate } \\
\left(l / \min _{\beta}\right)\end{array}$ & $\begin{array}{c}\text { Spray quantity }{ }^{\alpha)} \\
(l / \text { min }) \\
\gamma\end{array}$ \\
\hline Water & 2. 517 & 2. 360 & 0.157 \\
\hline DMF & 2.121 & 1. 755 & 0.366 \\
\hline DMSO & 1.859 & 1.585 & 0.274 \\
\hline
\end{tabular}

Air pressure : $0.5 \mathrm{~kg} / \mathrm{cm}^{2}$ const.

a) Spray quantity : $\gamma=\alpha-\beta$.

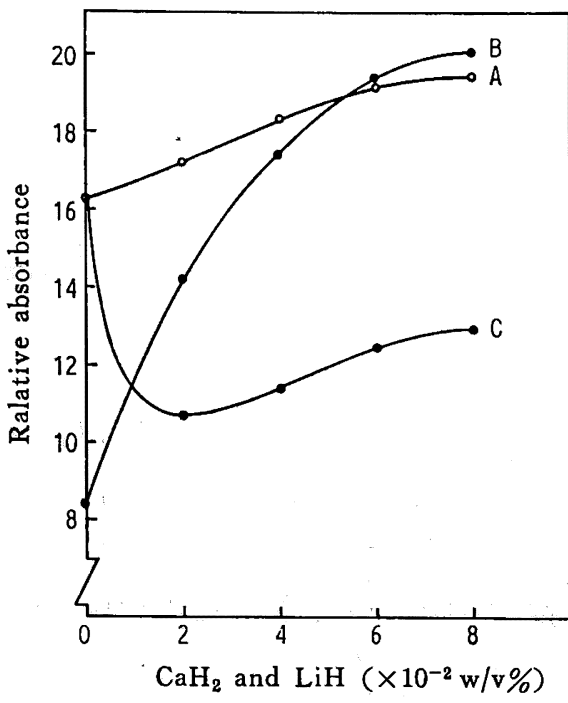

Fig. 2 Effect of calcium and lithium hydrides on magnesium absorbance using organic solvents

Sample: $\mathrm{MgCl}_{2}(\mathrm{Mg}, 0.05 \mathrm{ppm})+$ Reducing powders Solvent : A, C ; DMF, B ; DMSO

Reducing powders :

A, B ; Calcium hydride, C ; Lithium hydride Air flow rate : $13 l / \mathrm{min}$

Acetylene flow rate $: 1.8 \mathrm{l} / \mathrm{min}$

ムの場合は， $0.02 \mathrm{w} / \mathrm{v} \%$ の添加で約 $44 \%$ の減感を生じた。水素 化カルシウムの添加による感度の增大は，フレーム中に抹いて還 元雾囲気をつくりだし，金属酸化物の形成を抑制したためと考之 られる。

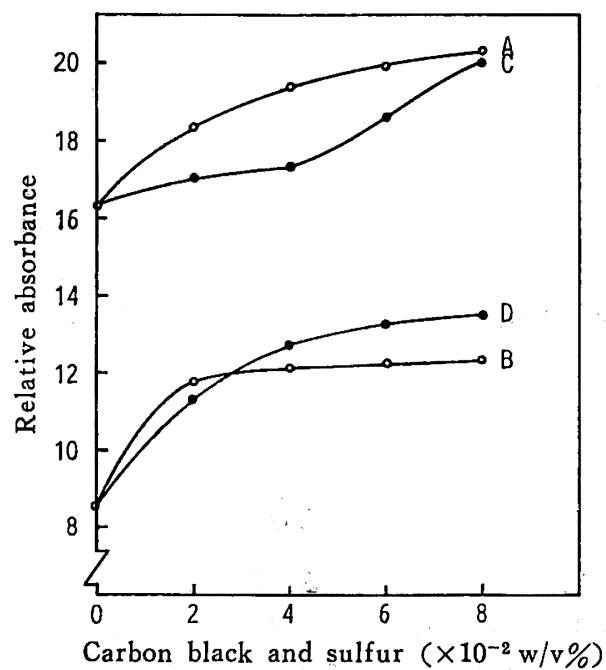

Fig. 3 Effect of carbon black and sulfur on magnesium absorbance in organic solvents

Sample: $\mathrm{MgCl}_{2}(\mathrm{Mg}, 0.05 \mathrm{ppm})+$ Reducing powders

Solvent : A, C ; DMF, B, D ; DMSO

Reducing powders : A, B ; Carbon black $C, D$; Sulfur

Air flow rate $: 13 l / \mathrm{min}$

Acetylene flow rate $: 1.8 \mathrm{l} / \mathrm{min}$ 
Table 3 Effect of reducing powders on chloride, sulfate and nitrate of magnesium in various solvents

\begin{tabular}{lrrrrrrr}
\multirow{2}{*}{ Element } & \multicolumn{3}{c}{$\mathrm{MgCl}_{2}$} & \multicolumn{3}{c}{$\mathrm{Mg}\left(\mathrm{NO}_{8}\right)_{2}$} \\
\cline { 2 - 5 } \cline { 6 - 8 } & Water & DMF & DMSO & Water & Water & DMF & DMSO \\
\hline Carbon black & +143 & +47 & +48 & +129 & +116 & +41 & +43 \\
Calcium hydride & - & +20 & +141 & - & - & +13 & +117 \\
Sulfur & 0 & +29 & +58 & 0 & 0 & +22 & +45 \\
$+\quad:$ Increase. & & & & & & & \\
Reducing powders added : $0.08 \mathrm{w} / \mathrm{v} \%$. & & & & &
\end{tabular}

一方，硫黄拉よび CB の添加効果を DMF および DMSO 中 で検討した結果を図 3 に示した。硫黄および CB の添加量は, キ ヤピラリーの目詰まりが起こらない $0.08 \mathrm{w} / \mathrm{v} \%$ 以下で検討し た。その結果，DMF および DMSO 溶液中においては類似の効 果を示し，DMF 溶液中では約 25\%,DMSO 中では約 50\%の 増感が認められた。

\section{4 マグネシウム塩に対する添加効果の比較}

表 3 はマグネシウムの塩酸塩，硝酸塩おさざ硫酸塩を用い，そ れぞれ水, DMF および DMSO 溶液中において添加効果を比較
した結果を示した。各塩によって感度および増感効果は異なり， 塩ではマグネシウムの塩酸塩がもっとも効果があった。還元性粉 体の添加では， CB が水溶液中に扎いて有効であり，さらに， DMF および DMSO 溶液中においては, 水素化カルシウム, 硫 黄の順に増感作用が認められた。DMF および DMSO を溶媒と したときの溶媒効果は DMF の方が大であったが, 還元性粉体の 増感効果は, DMSO 溶液中の方が効果があった。また，それらの 溶媒の使用は, 水溶液の場合よりも長時間安定な還元性粉体の分 散液を調製することができ，精度のよい分析值が得られた。

\title{
Synergistic Effect of Reducing Powders and Organic Solvents on the Flame Atomic Absorption Spectrometry of Magnesium
}

\author{
Chozo Yoshimura and Takayoshi Huzino* \\ Department of Applied Chemistry, Faculty of Science and Engineering, Kinki University ; \\ Kowakae, Higashiosaka-shi 577 Japan
}

The effect of reducing powders (metal hydrides, sulfur and carbon black) were compared and scrutinized on the flame atomic absorption spectrometry of magnesium, which shows the highest degree of enhancement by the addition of reducing powders among alkaline earth metals. Measurement was carried out after dispersing these reducing powders by ultrasonic agitator in sample solution that contained $0.05 \mu \mathrm{g} / \mathrm{m} l$ of magnesium in water, $\mathrm{N}, \mathrm{N}$-dimethylfolmamide (DMF) or dimethyl sulfoxide (DMSO). Absorbance increased about 2.5 times for DMSO solution with the addition of $0.08 \mathrm{w} / \mathrm{v} \%$ calcium hydride and about 1.2 times for DMF, compared with the absence of the reducing powder. Synergistic effect of organic solvents was also observed. 